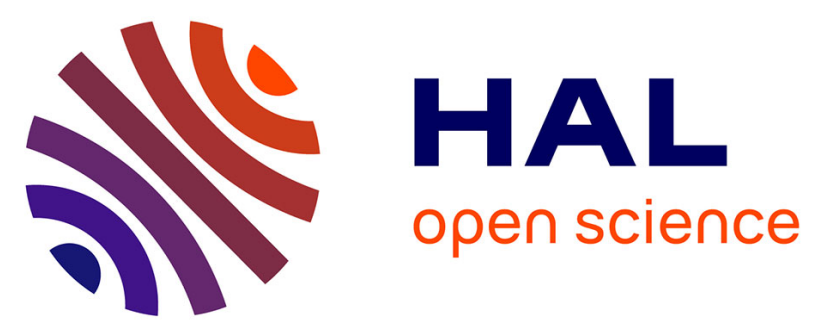

\title{
Comparative bioaccumulation kinetics of trace elements in Mediterranean marine sponges
}

Grégory Genta-Jouve, Nadja Cachet, François Oberhänsli, Charlotte Noyer, Jean-Louis Teyssié, Olivier P Thomas, Thomas Lacoue-Labarthe

\section{To cite this version:}

Grégory Genta-Jouve, Nadja Cachet, François Oberhänsli, Charlotte Noyer, Jean-Louis Teyssié, et al.. Comparative bioaccumulation kinetics of trace elements in Mediterranean marine sponges. Chemosphere, 2012, 89, pp.340-349. 10.1016/j.chemosphere.2012.04.052 . hal-01070265

\section{HAL Id: hal-01070265 https://hal.science/hal-01070265}

Submitted on 6 Oct 2014

HAL is a multi-disciplinary open access archive for the deposit and dissemination of scientific research documents, whether they are published or not. The documents may come from teaching and research institutions in France or abroad, or from public or private research centers.
L'archive ouverte pluridisciplinaire HAL, est destinée au dépôt et à la diffusion de documents scientifiques de niveau recherche, publiés ou non, émanant des établissements d'enseignement et de recherche français ou étrangers, des laboratoires publics ou privés. 


\section{Comparative bioaccumulation kinetics of trace elements in}

\section{Mediterranean marine sponges}

Grégory Genta-Jouve ${ }^{1}$, Nadja Cachet ${ }^{1}$, François Oberhänsli ${ }^{2}$, Charlotte Noyer ${ }^{3}$, Jean-Louis Teyssié $^{2}$, Olivier P. Thomas ${ }^{1}$, Thomas Lacoue-Labarthe ${ }^{2}$

\footnotetext{
${ }^{1}$ University of Nice-Sophia Antipolis, Nice Institute of Chemistry-PCRE, UMR 7272 CNRS, Faculté des Science, Parc Valrose, 06108 Nice Cedex 02, France

${ }^{2}$ International Atomic Energy Agency - Environment Laboratories, 4 Quai Antoine I ${ }^{\mathrm{er}}$, MC 98000 Monaco, Monaco

${ }^{3}$ Department of Marine Ecology, Centro de Estudios Avanzados de Blanes (CEAB, CSIC), Acceso Cala St. Francesc 14, Blanes 17300, Girona, Spain
}

$\begin{array}{ll}\text { Correspondence to: } & \text { T. Lacoue-Labarthe } \\ & \text { Present address: } \\ & \text { IAEA-EL } \\ & \text { Radioecology Laboratory } \\ & \text { 4 Quai Antoine Ier } \\ \text { MC-98 000 Monaco } \\ \text { E-mail: tlacouel@gmail.com }\end{array}$




\begin{abstract}
While marine organisms such as bivalves, seagrasses and macroalgae are commonly used as biomonitors for the environment pollution assessment, widely distributed sponges received little attention as potential helpful species for monitoring programmes. In this study, the trace element and radionuclide bioaccumulation and retention capacities of some marine sponges were estimated in a species-comparative study using radiotracers technique. Six Mediterranean species were exposed to background dissolved concentrations of ${ }^{110 \mathrm{~m}} \mathrm{Ag}$, ${ }^{241} \mathrm{Am},{ }^{109} \mathrm{Cd},{ }^{60} \mathrm{Co},{ }^{134} \mathrm{Cs},{ }^{54} \mathrm{Mn},{ }^{75} \mathrm{Se}$ and ${ }^{65} \mathrm{Zn}$ allowing the assessment of the uptake and depuration kinetics for selected elements. Globally, massive demosponges Agelas oroides, Chondrosia reniformis and Ircinia variabilis displayed higher concentration factor (CF) than the erectile ones (Acanthella acuta, Cymbaxinella damicornis, C. verrucosa) at the end of exposure, suggesting that the morphology is a key factor in the metal bioaccumulation efficiency. Considering this observation, two exceptions were noted: 1) A. acuta reached the highest $\mathrm{CF}$ for ${ }^{110 \mathrm{~m}} \mathrm{Ag}$ and strongly retained the accumulated metal without significant $\mathrm{Ag}$ loss when placed in depuration conditions; 2) $C$. reniformis did not accumulate Se as much as $A$. oroides and I. variabilis. These results suggest that peculiar metal uptake properties in sponges could be driven by specific metabolites or contrasting biosilification processes between species, respectively. This study demonstrated that sponges could be considered as valuable candidate for biomonitoring metal contamination but also that there is a need to experimentally highlight metal-dependant characteristic among species.
\end{abstract}

\title{
Keyword:
}

radiotracer

biokinetic

biomonitor

metal

radionuclide 


\section{Introduction}

The coastal environment is continuously loaded with foreign chemicals such as metals originated from the anthropogenic activities, i.e. by urban communities and industries, and released through the river inputs. Therefore, the fate and effects of these contaminants in aquatic ecosystems have been extensively studied by environmental toxicologists (van der Oost et al., 2003, Johnston and Roberts, 2009). In order to ensure the survey of the marine environment submitted to this anthropogenic contamination, researchers have developed a large array of biomonitoring tools that allow time- and biological integrated measures of the contaminants levels and their potential effects on biota (Philipps, 1990; Rainbow \& Philipps, 1993). Three kinds of biomonitors were proposed, requiring the selection of organisms according to criteria such as sedentary, easy identification, dense population, wide dispersion, and longevity (e.g. Rainbow, 1995). The presence/absence of a "sentinel" species is first used as a clue of long-term effects of contamination on populations and communities. The survey of biological responses at the infra-individual scale can also be used as a biomarker of exposure or effect at short-term scale (Lyons et al., 2010). Finally, organisms that are able to accumulate chemicals are used to monitor the bioavailable fraction of contaminants in the environment (Zhou et al., 2008). An efficient characterization of the contamination state of an ecosystem must rely on several species that could reflect the potential sources of pollutants, i.e. waterborne, particular or trophic and sediments (Rainbow, 1995). Consequently, there is a continuous need for new marine biomonitors in order to encompass the most significantly an ecosystem (Conti et al., 2008).

Benthic species such as bivalves, seagrasses and macroalgae have been commonly used as biomonitors of a metal contamination (Roberts et al., 2008). Considering the renowned characteristics of appropriate biomonitors, marine sponges are undoubtedly candidates for more detailed investigations. Sponges are sessile marine invertebrates that are able to filter large volumes of seawater and this characteristic will undoubtedly favor metal accumulation from dissolved and associated trace elements (Pérez, 2000). Indeed, previous studies demonstrated their high capacities to accumulate and to concentrate metals from the field and they were already proposed as biomonitors of a metal contamination (Hansen et al., 1995; Pérez et al., 2005; Cebrian et al., 2007; Venkateswara Rao et al. 2009; Pan et al., 2011; de Mestre et al., 2012). The high bioaccumulation factors measured for some species rendered them suitable for the tracing of elements at very low concentration in the water column. Sponges are widely distributed in the sublittoral area and they can dominate both in terms of 
diversity and biomass benthic communities from temperate rocky bottoms to polar continental shelf. Furthermore, they are known to tolerate a high level of contaminations in most cases. For these reasons, they have been proposed for a 'Sponge Watch Program', additional to the 'mussel watch' (Patel et al., 1985; Hansen et al., 1995; Pérez, 2000).

Surprisingly, the uptake and loss kinetics of trace metal elements have been poorly studied in sponges even if these data are essential for several reasons (Patel et al., 1984, 1985; Hansen et al., 1995). A high concentration factor is often required for a reliable monitoring of a contamination and the uptake and elimination rates of a trace element are complementary data to assess the efficiency of an organism to "register" an environmental contamination. Furthermore, these rates give access to the exposure time required to obtain this information, but also to the "storage" period during which the information is present in the organism. Consequently, these kinetics data will give valuable information for the use of a sponge species as a trace element biomonitor. High uptake rates will be required for the use of sponges as sentinel to quickly identify a contamination. Furthermore, low loss rates will leave traces of an old incident while high loss rates would rather be needed to follow the decontamination process of the water medium. Although it is well known that sponges can accumulate metal efficiently, very little information is available on the contrasting bioaccumulation capacities among species from the same area (Pérez et al. 2004; Pan et al., 2011). The primary objective of the present work was to investigate and to compare the uptake and loss kinetics of trace elements from waterborne pathway by six taxonomically diverse sponge species, highly represented in the coralligenous of the Mediterranean Sea, namely Acanthella acuta, Cymbaxinella damicornis (previously Axinella damicornis), Cymbaxinella verrucosa (previously Axinella verrucosa), Agelas oroides, Chondrosia reniformis and Ircinia variabilis, and then to identify their main features as potential biomonitors. Trace elements, $\mathrm{Ag}, \mathrm{Mn}, \mathrm{Zn}, \mathrm{Se}, \mathrm{Cd}, \mathrm{Co}, \mathrm{Cs}$ and $\mathrm{Am}$, were chosen among essential and non essential elements using $\gamma$-radiotracers in order to follow the bioaccumulation of these elements in a highly sensitive manner. Bioaccumulation studies have already been reported on some of these sponge species, mainly with the aim to obtain the concentration factors of trace elements comparing with the concentration of these elements in the water column or the sediments (Cebrian et al., 2003, 2006, 2007 and Pérez et al. 2004). These results showed contrasting results relative to accumulation and suitability for the assessment of marine environmental quality. In our study we decided to reinvestigate some of these species as biomonitors of a trace element contamination but most importantly 
in order to give important kinetic data on the uptake and loss properties of these trace elements.

\section{Materials and methods}

1. Target species

The target species were six Mediterranean sponges, namely Acanthella acuta (Schmidt, 1862); Agelas oroides (Schmidt, 1864); Cymbaxinella damicornis (Esper, 1794); Cymbaxinella verrucosa (Esper, 1794); Chondrosia reniformis (Nardo, 1847), and Ircinia variabilis (Schmidt, 1864). These sponges were selected because of a wide sublittoral or circalittoral distribution in the western Mediterranean Sea. They were also chosen as sufficiently diverse from a taxonomical point of view and well described with regard to their morphology and cytology as summarized below (Hooper and van Soest, 2002):

a) Chondrosia reniformis (Class: Demospongiae, Order: Chondrosida, Family: Chondrillidae) is a thick encrusting species predominantly composed of collagen and lacking a fiber skeleton (mineral or spongin). Thus, the mesohyl is thick and well developed, whereas the aquiferous system is reduced. This species is also considered to be a sensitive organism that has difficulty to survive in polluted habitats (Cebrian et al., 2006).

b) Agelas oroides (Class: Demospongiae, Order: Agelasida, Family Agelasidae) is a massive sponge with irregular lobes. Oscules are large, circular, and distributed at the top of the lobes and its spicules attached in a well-developed spongin fiber skeleton.

c) Ircinia variabilis (Class: Demospongiae, Order: Dictyoceratida, Family: Irciniidae) is a massive sponge. Oscules are large and located at the top of the conical lobes. This species does not have mineral spicules but a dense fiber skeleton structurally diverse from classical spongins (Junqua et al. 1974).

d) Acanthella acuta (Class: Demospongiae, Order: Axinellida, Family: Dictyonellidae) is a small erect sponge with rather small oscules and a skeleton of silica spicules responsible for its fibrous quality.

e) Cymbaxinella damicornis (Class: Demospongiae, Order: Axinellida, Family: Axinellidae) is a rather small branching-erect sponge with small and compressed branches. Oscules are small and are located on the apices of the branches, partially surrounded by a small triangular 'flap' of tissue. The skeleton is constituted of silica spicules that are axially condensed and embedded in spongin fibers. 
f) Cymbaxinella verrucosa (Class: Demospongiae, Order: Axinellida, Family: Axinellidae) is a branching-erect sponge with an arborescent shape and cylindrical branches. Oscules are small and rather circular and its skeleton is composed of silica spicules that are axially condensed and embedded in spongin fibers.

\section{Collection site, radiotracer and experimental design}

Three specimens of each sponge species were sampled off the Fontvieille harbor at St Nicolas rocks in Monaco by SCUBA between 20 and 35 meters depth in June 2008. Individuals were selected of a homogenous size, with an average length of $7 \pm 2 \mathrm{~cm}$ for the branch-erect sponges (A. acuta, C. damicornis and C. verrucosa) and an average diameter of $5 \pm 2 \mathrm{~cm}$ for the massive sponges (A. oroides, I. variabilis and C. reniformis), Immediately after collection, sponges were kept in seawater at constant temperature during their transfer to the aquaria within 30 minutes.

At the laboratory, sponges were acclimated during 2 weeks in the aquarium conditions with flowing seawater. Then, individuals were transferred into a $70 \mathrm{~L}$ closed-circuit tank with stabilized environmental conditions: $0.45 \mu \mathrm{m}$ filtered and U.V sterilized seawater; temperature $19 \pm 1{ }^{\circ} \mathrm{C}$; salinity $38 \mathrm{~g} \mathrm{~L}^{-1}$; $\mathrm{pH} 8.02$; light/dark cycle, $12 \mathrm{~h} / 12 \mathrm{~h}$. In these conditions, they were further exposed to dissolved radiotracers for 170 hours. Sponges were fed daily with Isochrysis galbana at a concentration of $10^{5}$ cells $1^{-1}$. No mortality was observed during these experimental conditions.

Eight radiotracers $\left({ }^{110 \mathrm{~m}} \mathrm{Ag},{ }^{241} \mathrm{Am},{ }^{109} \mathrm{Cd},{ }^{60} \mathrm{Co},{ }^{134} \mathrm{Cs},{ }^{54} \mathrm{Mn},{ }^{75} \mathrm{Se}\right.$ and $\left.{ }^{65} \mathrm{Zn}\right)$ were used dissolved in seawater to follow the bioaccumulation behaviors of both anthropogenic radionuclides released from the nuclear facilities (e.g. $\left.{ }^{110 \mathrm{~m}} \mathrm{Ag},{ }^{241} \mathrm{Am},{ }^{60} \mathrm{Co},{ }^{134} \mathrm{Cs},{ }^{54} \mathrm{Mn}\right)($ e.g. Warnau et al., 1999; Ke et al., 2000) and corresponding stable metals discharged in marine waters (e.g. Warnau and Bustamante, 2007). They were chosen because of their large spectrum of physico-chemical properties and their different contribution to a marine contamination. The radioisotopes were obtained from Amersham $\left({ }^{241} \mathrm{Am},{ }^{109} \mathrm{Cd},{ }^{60} \mathrm{Co},{ }^{134} \mathrm{Cs}\right)$, Isotope Products $\left({ }^{54} \mathrm{Mn},{ }^{65} \mathrm{Zn}\right)$ and Polatom $\left({ }^{10 \mathrm{~m}} \mathrm{Ag},{ }^{75} \mathrm{Se}\right)$. Isotopes were dissolved in $0.1 \mathrm{~N}$ $\mathrm{HCl}\left({ }^{109} \mathrm{Cd},{ }^{54} \mathrm{Mn},{ }^{60} \mathrm{Co}\right), 0.5 \mathrm{~N} \mathrm{HCl}\left({ }^{65} \mathrm{Zn}\right), 0.1 \mathrm{~N} \mathrm{HNO}_{3}\left({ }^{110 \mathrm{~m}} \mathrm{Ag},{ }^{241} \mathrm{Am}\right)$, or pure water $\left({ }^{134} \mathrm{Cs}\right)$. Isotopes were spiked by additions of microliters of these stock solutions in the seawater to obtain the following activities $\left({ }^{110 \mathrm{~m}} \mathrm{Ag} 0.5 \mathrm{kBq} \mathrm{L}{ }^{-1},{ }^{241} \mathrm{Am} 0.2 \mathrm{kBq} \mathrm{L}{ }^{-1},{ }^{109} \mathrm{Cd}_{1.3}\right.$ $\mathrm{kBq} \mathrm{L}-1,{ }^{60} \mathrm{Co} 0.5 \mathrm{kBq} \mathrm{L}{ }^{-1},{ }^{134} \mathrm{Cs} 1.0 \mathrm{kBq} \mathrm{L}{ }^{-1},{ }^{54} \mathrm{Mn} 0.5 \mathrm{kBq} \mathrm{L}{ }^{-1},{ }^{75} \mathrm{Se} 0.5 \mathrm{kBq} \mathrm{L}{ }^{-1},{ }^{65} \mathrm{Zn} 0.5 \mathrm{kBq}$ $\left.\mathrm{L}^{-1}\right)$. For trace elements, these additions increased the concentrations by $400 \mathrm{pM} \mathrm{Ag}, 4.6 \mathrm{fM}$ 
${ }^{241} \mathrm{Am}, 3.4 \mathrm{pM} \mathrm{Cd}, 0.1 \mathrm{pM}$ Co, $1.4 \mathrm{nM}{ }^{134} \mathrm{Cs}, 83.4$ pM Mn, 80 pM Se, and $10 \mathrm{pM}$ Zn. The resulting concentrations stand below natural seawater concentrations of these elements (Bruland, 1983). No change of $\mathrm{pH}$ in the tank seawater was measured after radioisotope addition. During the experiment, seawater and radiotracer spikes were renewed daily during the first 5 days of incubation to maintain water quality and a constant radiotracer concentration after each injection. Radiotracer activities in seawater were checked after 24 , 48, 72, 98 and 170 hours of incubation, before and after each water renewal yielding timeintegrated activities in seawater for the 8 radiotracers of $0.33 \pm 0.18 \mathrm{kBq}{ }^{110 \mathrm{~m}} \mathrm{Ag} \mathrm{L}^{-1}, 0.16 \pm$ $0.05 \mathrm{kBq}{ }^{241} \mathrm{Am} \mathrm{L}{ }^{-1}, 0.85 \pm 0.11 \mathrm{kBq}{ }^{109} \mathrm{Cd} \mathrm{L}^{-1}, 0.46 \pm 0.05 \mathrm{kBq}{ }^{60} \mathrm{Co} \mathrm{L}^{-1}, 1.04 \pm 0.01 \mathrm{kBq}$ ${ }^{134} \mathrm{Cs} \mathrm{L}^{-1}, 0.44 \pm 0.10 \mathrm{kBq}{ }^{54} \mathrm{Mn} \mathrm{L}^{-1}, 0.46 \pm 0.03 \mathrm{kBq}{ }^{75} \mathrm{Se} \mathrm{L}^{-1}, 0.42 \pm 0.05 \mathrm{kBq}{ }^{65} \mathrm{Zn} \mathrm{L}^{-1}$ (Warnau et al., 1996). The metal uptake was followed by radiotracer activity counting in the tag-identified sponge sampled after 24, 48, 72, 98 and 170 hours of incubation. Each individual was sampled, rinsed in clean seawater to remove radiolabelled water from the aquifer system, weighted and radiocounted according to the method described below.

After the incubation period, the radiolabelled sponges were placed in an open-circuit $70 \mathrm{~L}$ tank and held for 7 weeks in clean and flowing water (seawater flux: $50 \mathrm{~L} \mathrm{~h}^{-1}$; temperature: $19^{\circ} \mathrm{C}$; salinity 38 p.s.u.; light/dark cycle $12 \mathrm{~h} / 12 \mathrm{~h}$ ). Sponges were sampled and counted every day during the first week and then weekly to establish the depuration kinetics of each radiotracer.

\section{Radioanalyses and data treatments}

Radioactivity in all samples was assessed using a high-resolution $Y$ spectrometry system consisting of four coaxial Germanium (N- or P-type) detectors (EGNC 33-195-R, Intertechnique) connected to a multi-channel analyzer (Interwinner6, Intertechnique). The radioactivity of the samples was determined by comparison with the radioactivity in standards of appropriate geometry and was corrected for background and radioisotope physical decay. Gamma emissions of ${ }^{110 \mathrm{~m}} \mathrm{Ag},{ }^{241} \mathrm{Am},{ }^{109} \mathrm{Cd},{ }^{60} \mathrm{Co},{ }^{134} \mathrm{Cs},{ }^{54} \mathrm{Mn},{ }^{75} \mathrm{Se}$ and ${ }^{65} \mathrm{Zn}$ were assayed at $657,60,88,1332,605,835,264$ and $1116 \mathrm{keV}$, respectively. Counting time was adjusted to obtain counting errors less than $5 \%$ but was limited to a maximum of 15 min to avoid stress induction for the organisms (Jeffree et al., 2010).

The uptake of radiotracer was expressed as changes in concentration factors $(\mathrm{CF})$, which is the ratio between radiotracer activity in the sponge $-\mathrm{Bq} \mathrm{g}^{-1}-$ and the time-integrated activity in seawater $-\mathrm{Bq} \mathrm{g}^{-1}$ (Metian et al., 2009). This unitless term expressed the efficiency 
of the organism to accumulate and concentrate an element from the seawater after a determined time of exposure.

Uptake kinetic was best described using either a linear equation (Eq. 1) or a saturation exponential equation (Eq. 2):

$\mathrm{CF}_{\mathrm{t}}=\mathrm{k}_{\mathrm{u}} \mathrm{t}$

$\mathrm{CF}_{\mathrm{t}}=\mathrm{CF}_{\text {ss }}\left(1-\mathrm{e}^{-\mathrm{ket}}\right)$

where $\mathrm{CF}_{\mathrm{t}}$ and $\mathrm{CF}_{\mathrm{ss}}$ are the concentration factors at time $\mathrm{t}(\mathrm{d})$ and at steady-state respectively, and $k_{\mathrm{e}}$ and $\mathrm{k}_{\mathrm{u}}$ are the biological depuration and uptake rate constants $\left(\mathrm{d}^{-1}\right)$ (Whicker and Schultz, 1982).

Radiotracer depuration kinetics was expressed in terms of change in percentage of remaining activity (i.e., radioactivity at time $\mathrm{t}$ divided by the initial radioactivity measured in the individual at the beginning of the depuration period * 100) along with time.

The depuration kinetics was best fitted by either a single- (Eq. 3) or a double- (Eq. 4) exponential equation:

$A_{t}=A_{0} e^{-k_{e} t}$

$A_{t}=A_{0 s} e^{-k e s t}+A_{01} e^{-k e l t}$

where $A_{t}$ and $A_{0}$ are the remaining activities at time $t(d)$ and 0 , respectively, $k_{e}$ is the biological depuration rate constant $\left(\mathrm{d}^{-1}\right)$, and « $\mathrm{s} »$ and « $1 »$ subscripts refer to the short- and long-lived component of the depuration kinetics (Warnau et al., 1996, 1999). The determination of $\mathrm{k}_{\mathrm{e}}$ allows the calculation of the radiotracer biological half-life (d) according to the relation:

$\mathrm{Tb}_{1 / 2}=\ln 2 / \mathrm{k}_{\mathrm{e}}$

Constants (and their statistics) of the best fitting uptake and depuration kinetic equations (decision based on ANOVA tables for two fitted model objects) were estimated by iterative adjustment of the models using the $n l s$ curve-fitting routine in $\mathrm{R}$ freeware. The level of significance for statistical analyses was always set at $a=0.05$. We also realized HCA and PCA on both $\mathrm{CF}_{170 \mathrm{~h}}$ and $\mathrm{T}_{\mathrm{b} 1 / 2}$ to clearly identify the different patterns in both uptake and loss rates.

\section{Results}

Radiotracer uptake kinetics in sponges 
The uptake kinetics of ${ }^{110 \mathrm{~m}} \mathrm{Ag},{ }^{241} \mathrm{Am},{ }^{109} \mathrm{Cd},{ }^{60} \mathrm{Co},{ }^{134} \mathrm{Cs},{ }^{54} \mathrm{Mn},{ }^{75} \mathrm{Se}$ and ${ }^{65} \mathrm{Zn}$ in the six sponge species are shown in Figure 1. In our experimental conditions, these elements were taken up in the whole-body of sponges following contrasting bioaccumulation patterns. Most of the uptake kinetics followed an exponential model (see Table 1) indicating that the accumulation of such trace elements in the sponge is limited by a steady-state equilibrium after 170 hours. On the contrary, the kinetics best fitted by a linear model indicated that optimal accumulation capacities for the species were not reached after time of exposure to dissolved radiotracers.

Overall, the $\mathrm{CF}$ reached at the end of the exposure duration $\left(\mathrm{CF}_{170 \mathrm{~h}}\right)$ varied according to the element with relative values as ${ }^{110 \mathrm{~m}} \mathrm{Ag} \approx{ }^{241} \mathrm{Am} \approx{ }^{65} \mathrm{Zn}>{ }^{54} \mathrm{Mn}>{ }^{109} \mathrm{Cd} \approx{ }^{60} \mathrm{Co} \approx{ }^{75} \mathrm{Se}>{ }^{134} \mathrm{Cs}$ for all species. Considering morphological differences between sponge species, it is worth noting higher concentration factors for massive sponges (I. variabilis, C. reniformis and A. oroides) than for the erect ones (A. acuta, C. damicornis and C. verrucosa) with the exception of $A$. acuta for an extremely high $\mathrm{CF}$ of ${ }^{110 \mathrm{~m}} \mathrm{Ag}$. More precisely, the analysis of the uptake rate $\left(\mathrm{k}_{\mathrm{u}}\right)$ calculated from the models and the CF reached at the end of the exposure duration $\left(\mathrm{CF}_{170 \mathrm{~h}}\right)$ highlighted contrasting metal bioaccumulation efficiencies in sponges with respect to the trace element and species. Thus, Acanthella acuta showed the highest accumulation efficiency for ${ }^{110 \mathrm{~m}} \mathrm{Ag}$ (i.e. $11.9 \pm 1.1 \mathrm{~h}^{-1}$ and $1895 \pm 896$ for $\mathrm{k}_{\mathrm{u}}$ and $\mathrm{CF}_{170 \mathrm{~h}}$, respectively; Table 1) whereas the lowest uptakes were observed for ${ }^{109} \mathrm{Cd}$ in Cymbaxinella verrucosa (i.e. $0.07 \pm$ $0.01 \mathrm{~h}^{-1}$ and $12 \pm 3$ for $\mathrm{k}_{\mathrm{u}}$ and $\mathrm{CF}_{170 \mathrm{~h}}$, respectively), ${ }^{75} \mathrm{Se}$ in Acanthella acuta (i.e. $0.02 \pm 0.001$ $\mathrm{h}^{-1}$ and $4 \pm 1$ for $\mathrm{k}_{\mathrm{u}}$ and $\mathrm{CF}_{170 \mathrm{~h}}$, respectively) and ${ }^{134} \mathrm{Cs}$ in all species. For this last radionuclide, it is noteworthy that the accumulation reached a steady-state equilibrium in all species close to $\mathrm{CF}_{\mathrm{ss}}$ value $\approx 1$, with the notable exception of a two-fold higher value observed in I. variabilis. $\left(\mathrm{CF}_{\mathrm{ss}}=1.8 \pm 0.1\right)$.

The multivariate analysis on the CF reached at the end of the waterborne exposure revealed that species could be gathered into two groups according to their bioaccumulation behaviors (Figure 3). The first cluster includes the species C. verrucosa, C. damicornis and A. acuta that are characterized by low accumulation efficiencies for all the trace elements compared to species gathered in the second cluster, i.e. A. oroides, C. reniformis and I. variabilis. However, within the first group, A. acuta distinguished from C. damicornis and C. verrucosa by a higher ${ }^{110 \mathrm{~m}} \mathrm{Ag}$ accumulation. In the second group, $C$. reniformis displayed a peculiar low uptake of ${ }^{75} \mathrm{Se}$ compared to A. oroides and I. variabilis $\left(\mathrm{CF}_{170 \mathrm{~h}}=12 \pm 1\right.$ in C. reniformis compared to $\mathrm{CF}_{170 \mathrm{~h}}=225 \pm 147$ and $217 \pm 63$ in A. oroides and I. variabilis) 


\section{Radiotracer loss kinetics in sponges}

The ${ }^{134}$ Cs loss was not followed in all species because radiotracer activities in sponges dropped below the detection limit after 1-2 $\mathrm{d}$ of depuration in natural seawater. Loss behaviors are quite similar for all trace elements and sponge species with the notable exception of ${ }^{110 \mathrm{~m}} \mathrm{Ag}$ in A. acuta which has an extremely low kinetics of depuration (Figure 2). Considering all species, it is noteworthy that most of the depuration kinetics were best fitted by a double exponential equation (Table 2) indicating that metals and radionuclides were released according to a weakly bound $\left(\mathrm{T}_{\mathrm{b}^{1 / 2}}<3 \mathrm{~d}\right.$; details not shown) component but also a tightly bound one $\left(\mathrm{T}_{\mathrm{b}^{1 / 2}}>1\right.$ month; Table 2$)$. Interestingly, in A. acuta, ${ }^{110 \mathrm{~m}} \mathrm{Ag}$ was lost following a single component equation giving a very high estimated biological half-life (i.e. $\mathrm{T}_{\mathrm{b}^{1 / 2}}=1100 \mathrm{~d}$ ). This result suggests that the accumulated metal is strongly retained by this species. Similarly, A. oroides and I. variabilis that accumulated the most efficiently ${ }^{75} \mathrm{Se}$ (Table 1) released this metal following a simple equation and with a $T_{b^{1 / 2}}$ of 112 and $197 d$, respectively.

\section{Discussion}

The assessment of the quality of the marine environment usually can be inferred from the presence/absence of a contaminant in the water column, the sediments or a living organism, but also from the physiological state of organisms. The target species used as biomonitor has to obey strong criteria such as sedentary, easy recognition, dense population, wild dispersion, and longevity (e.g. Rainbow and Philipps, 1993). Some sponge species have been already studied for this purpose and the results have been usually found to be encouraging (Cebrian et al. 2007; Pérez et al. 2005; Pan et al. 2011; Venkateswara Rao et al., 2009). Indeed, sponges are widely distributed and they may represent the most prominent group of macroinvertebrates in a given ecosystems where usual bioindicator (e.g. mussel) are missing (Pérez et al., 2005). Moreover, their tolerance to physico-chemical fluctuations allows them to be present both in polluted and non-contaminated seawater (de Mestre et al. 2012). Their simple tissue organization and their biology as active filter favor the concentration and accumulation of contaminants from both dissolved and particulate phases. Basically, sponges from the field are therefore well known as bioaccumulator of hydrocarbons (Féral et al., 1979), organochlorinated compounds (e.g. Verdenal et al., 1990, Pérez et al., 2003) and metals (e.g. Verdenal et al., 1990; Hansen et al., 1995; Cebrian et al., 2003; Pérez et al. 2005; Pan et al., 2011). Nevertheless, a "Sponge Watch program" has surprisingly been little used for field 
surveys of contamination level. Only few works delineated the bioaccumulation fate of contaminating metals in a limited number of sponge species (Patel et al., 1985; Hansen et al., 1985; Cebrian et al., 2003). However, these values are of high interest to discriminate between a regulation and a net accumulation of the trace elements in the studied organism (Rainbow and Philipps, 1993). In this study, it must be emphasized that the bioaccumulation capacities of sponges are higher than those found for other marine biomonitors. In similar experimental conditions, $\mathrm{CF}$ values of the same order of magnitude were reached only after 40 days of exposure in mussels Mytilus edulis and Mytilus chilensis (Hervé-Fernandez et al., 2010; unpublished data). It is also noteworthy that Ag CF in Acanthella acuta is two-fold higher that this determined in clams Gafrarium tumidum after two weeks of exposure (Hedouin et al., 2006).

Our comparative study on six diverse Mediterranean sponge species and eight trace elements revealed two major contrasting bioaccumulation trends. The massive sponges Agelas oroides, Chondrosia reniformis and Ircinia variabilis displayed the highest concentration factors after $170 \mathrm{~h}$ of exposure compared to the other three species (Figure 2) for most of the considered radiotracers with $\mathrm{CF}$ maximum values around 700 (Figure 1; Table 1). The separation into two groups is in accordance with previous studies showing that trace element accumulation vary between sponge species (Figure 3) (Patel, 1985; Pérez et al. 2004; Cebrian et al. 2007; Venkateswara Rao et al. 2009; Pan et al., 2011). Metal specificity and species specific variability in the BC factors within sponges has been previously documented (Patel, 1985; Pérez et al. 2004; Cebrian et al. 2007; Pan et al., 2011).

This ability of sponges to highly bioaccumulate trace elements both dissolved in the seawater or adsorbed on particles was already reported and mainly inferred to their high pumping flow and filtering activity (Turon et al. 1997). The interspecific variability might be explained by different pumping ability of sponge species (Cebrian et al., 2007). Indeed, massive sponges possess higher choanocyte chamber volumes and consequently a much higher area to bind trace elements. These interactions may often be of low energy and could explain the usual loss kinetic patterns of most of the studied elements. The role of the associated microorganisms is an important issue to be addressed in the context of an interspecific variation in the bioaccumulation processes (Selvin et al. 2009; Erwin et al. 2011). Indeed, it is well known that marine sponges can be associated to a diverse array of microbial symbionts which appeared to be sponge-specific in some cases. These microorganisms should also play a role in the bioaccumulation processes of trace elements (Gadd, 1990) and may explain the interspecific differences (Selvin et al., 2009). In our case, the six studied species are 
considered as HMA (High Microbial Abundance) sponge species (Taylor et al. 2007, Weisz et al., 2008, Erwin et al., 2011) and then the interspecific bioaccumulation differences cannot be inferred to microbial density but rather to distinct microbial populations into these species. Further investigations are required to assess the exact role of the associated microorganisms into these processes.

Among the studied trace elements, americium is an actinide of high interest as an anthropogenic radionuclide. Our study demonstrated that massive sponges can serve equally as biomonitors of an Am contamination with very high CF values and rapid loss kinetics. As a transuranic radionuclide, americium (III) is strongly particulate reactive (Ryan, 2002; Metian et al., 2011). These three species can also serve as biomonitors for $\mathrm{Zn}, \mathrm{Mn}$ and Co even if the CFs are two magnitude lower for this latter trace element. Cadmium is also very important to monitor in the marine environment as this trace element has been proven to induce toxicity in several phytoplanktonic micro-organisms (Höss et al., 2011). Among our studied species, both Agelas oroides and Chondrosia reniformis were identified as the best sponge biomonitors in the Mediterranean Sea to follow Cd contamination.

This study also highlighted some interesting specificity within both massive and erect sponge groups concerning the concentration capacities of trace elements (Figure 3). Indeed, 1) among the "low uptake" species, Acanthella acuta displayed the highest uptake of Ag, whereas 2) the "high uptake" species, Chondrosia reniformis did not accumulate Se as much as Agelas oroides and Ircinia variabilis. In these cases low loss rates suggested a net accumulation mechanism instead of a simple regulation. In our study, Acanthella acuta differed from all other sponge species by a very high accumulation of dissolved $\mathrm{Ag}$ (i.e. ${ }^{110 \mathrm{~m}} \mathrm{Ag} \mathrm{CF}=1895 \pm$ 896 at $170 \mathrm{~h}$ of exposure). Moreover, all elements $\left(\mathrm{A}_{01}=95 \%\right.$; Table 2$)$ are also strongly retained by this sponge. During the observation period, the estimated $\mathrm{T}_{\mathrm{b} 1 / 2}$ was $1093 \mathrm{~d}$ (Table 2), suggesting that Ag is efficiently accumulated and tightly bound to specific sites of the sponge. Interestingly and unlike other studied species, A. acuta is well known to produce some secondary metabolites that include high concentrations of sulfurated compounds (Ciminiello et al., 1987) and isocyanates sesquiterpenes (Mayol et al., 1987) that could exhibit a high affinity for Ag (Eisler, 1996). This observation suggests a role of the biomolecules and especially the secondary metabolites in the bioaccumulation of trace elements by sponges but further studies need to be conducted to identify the putative complex between silver and these ligands.

A second atypical behaviour was observed for Selenium. This transition metal plays a very important role in the environment and for human health and then its concentration must be 
precisely followed in the marine environment (Winkel et al. 2012). Among the three species that showed the highest accumulation efficiencies of trace elements, Chondrosia reniformis did not accumulate Se as efficiently as Agelas oroides and Ircinia variabilis $\left(\mathrm{CF}_{170 \mathrm{~h}}=12 \pm 1\right.$ in C. reniformis vs. $225 \pm 147$ and $217 \pm 62$ in A. oroides and I. variabilis respectively). In these two latter species, the major fraction of accumulated Se $(>94 \%)$ is tightly bound to sponge tissue with estimated $\mathrm{T}_{\mathrm{b}^{1 / 2}}$ of 112 and $197 \mathrm{~d}$, respectively. Selenium is an essential element but toxic in large amount, known for its function as an active co-factor or components of enzymes such as glutathione peroxidase or thioredoxin reductase (Mertz, 1981) which present a selenocysteine into their primary structure (Stadtman, 1996). Moreover, Se was proved to stimulate the sponge biosilification of spicules but the mechanism is still unknown (Müller et al., 2005, Schwertner et al. 2006). A gene coding for a selenoprotein was found to be up-regulated in a Suberites sponge. Difference in the rate of the biosilification processes between our studied sponges may then explain the high incorporation and low depuration of this element in some species.

Among the analyzed elements, the uptake kinetics of ${ }^{134} \mathrm{Cs}$ in all species displayed a steady state equilibrium rapidly reached during the experiment duration (Table 1). Compared to the other element, $\mathrm{CF}_{\mathrm{ss}}$ values were very low and estimated close to 1 , suggesting that this radionuclide was in equilibrium between the whole body of sponge and the surrounding water. This result has to be related to the physico-chemicals properties of $\mathrm{Cs}$, an alkaline highly hydrosoluble and with very low coordination constants with any ligand. It is also assumed that low Cs bioaccumulation might be enhanced by competitive inhibition by the over-whelmingly high concentration of $\mathrm{K}^{+}$in the seawater (Bryan, 1963; Wang et al., 2000). This element is rather known to follow the water movement from seawater to the tissues (Lacoue-Labarthe et al., 2010; Metian et al., 2011). Therefore, the ${ }^{134}$ Cs activity detected in each individual might reflect the water volume contented in the whole-body of sponge. Nevertheless, I. variabilis displayed a 2-fold higher Cs uptake efficiency with an estimated $\mathrm{CF}_{\mathrm{ss}}$ of $1.8 \pm 0.1$ and a $\mathrm{CF}_{170 \mathrm{~h}}$ of $2.0 \pm 0.4$ (Table 1$)$.

Our work contributed to confirm that trace element bioaccumulation efficiencies are species-specific among sponges (Patel et al., 1985; Pan et al., 2011). Using radiotracers at relevant concentrations, the uptake and loss parameters observed in this work suggest that Agelas oroides, Chrondrosia reniformis and Ircinia variabilis present the adequate characteristics of a biomonitor, as they would readily reveal an environmental contamination by any of the studied elements, except for ${ }^{134} \mathrm{Cs}$. Agelas oroides and Chondrosia reniformis have already been proposed for such purpose by Pérez et al. (2004). The loss kinetics of all 
trace elements in Ircinia variabilis is around $40 \%$ longer comparing to other species in average which indicates that this species would allow a long-term integrated measure $\left(\mathrm{T}_{\mathrm{b}^{1 / 2}}>\right.$ $66 \mathrm{~d}$ ) of the bioavailable fraction from dissolved contaminants, especially for ${ }^{110 \mathrm{~m}} \mathrm{Ag},{ }^{109} \mathrm{Cd}$, ${ }^{60} \mathrm{Co},{ }^{54} \mathrm{Mn}$ and ${ }^{75} \mathrm{Se}$. Among all, Acanthella acuta is remarkable because of its high ${ }^{110 \mathrm{~m}} \mathrm{Ag}$ uptake capacity and the total retention of the quasi-totality of accumulated metal $\left(\mathrm{A}_{01}=95 \%\right)$. As Ag is well known to be mainly accumulated from waterborne pathway, e.g. in bivalves (Wang et al., 1996, Metian et al., 2008), in crustacean (Metian et al., 2010), or in cephalopod (Bustamante et al., 2004), A. acuta appears therefore as a good biomonitor for a contamination by this element. This result underlines the need to perform the trace metal analysis on a large array of sponge species before choosing the right sponge sentinel. This also strongly suggests that several sponge species could be valuable candidates as sentinel of a trace metal contamination and that massive sponges appear as better candidate than brancherected congeners. It would also be interesting to extend this approach to encrusting sponges even if the experimental design would be much more complicated (de Mestre et al. 2012).

In summary, the uptake and loss kinetic data of trace elements into the organism appear essential to fully characterized the bioaccumulation properties of marine species and to validate their role as biomonitor, reflecting a time-integrated picture of the contamination state of the environment. A net accumulation of silver in A. acuta and selenium in A. oroides and Ircinia variabilis strongly suggest an important role as chelators for the metabolites present in these species. Additional insights into the speciation of these elements into the water column and the tissue animals will also be of high interest to fully understand the processes behind trace metal bioaccumulations. These results also raise the question of the fate of the highly accumulated element into sponge tissues, in terms of storage, detoxification process and potential role in the metabolism. Another very important issue is related to the presence of associated microorganisms in these complex invertebrates, which can play an important role in the processes of trace element bioaccumulation.

\section{Acknowledgement}

The International Atomic Energy Agency is grateful to the Government of the Principality of Monaco for the support provided to its Environment Laboratories. We thank the Conseil Régional Provence Alpes Côte d'Azur, the French ANR (www.ecimar.org, ANR-06-BDIV-001) and the European Union through the BIOCAPITAL UE grant (MRTN-CT-2004-512301) for financial supports (G.G.J and 
C.N.). T. Pérez (DIMAR, Marseille) is greatly acknowledged for his help in the sponge identification and fruitful discussions.

\section{References}

Bruland, K.D., 1983. Trace elements in seawater, in: Riley, J.P., Chester, R. (Eds.), Chemical oceanography. Academic Press, London, pp. 157-201.

Bryan, G.W., 1963. The accumulation of radioactive caesium by marine invertebrates. Journal of the Marine Biological Association of the United Kingdom 43, 519-539.

Bustamante, P., Teyssié, J.-L., Danis, B., Fowler, S.W., Miramand, P., Cotret, O., Warnau, M., 2004. Uptake, transfer and distribution of silver and cobalt in tissues of the common cuttlefish Sepia officinalis at different stages of its life cycle. Mar. Ecol. Prog. Ser. 269, 185-195.

Cebrian, E., Agell, G., Marti, R., Uriz, M.J., 2006. Response of the Mediterranean sponge Chondrosia reniformis Nardo to copper pollution. Environ. Pollut. 141, 452-458.

Cebrian, E., Marti, R., Uriz, J.M., Turon, X., 2003. Sublethal effects of contamination on the Mediterranean sponge Crambe crambe: metal accumulation and biological responses. Mar. Pollut. Bull. 46, 1273-1284.

Cebrian, E., Uriz, M.J., Turon, X., 2007. Sponges as biomonitors of heavy metals in spatial and temporal surveys in northwestern Mediterranean: Multispecies comparison. Environ. Toxicol. Chem. 26, 2430-2439.

Ciminiello, P., Magno, S., Mayol, L., Piccialli, V., 1987. Cis-eudesmane nitrogenous metabolites from the marine sponges Axinella cannabina and Acanthella acuta. J. Nat. Prod. 50, 217-220.

Conti, M.E., Iacobucci, M., 2008. Marine organisms as biomonitors, in: Conti, M.E. (Ed.), Biological monitoring: theory and applications. WITpress, Roma, Italy, pp. 81-110.

Eisler, R., 1996. Silver hazards to fish, wildlife and invertebrates: a synoptic review, Contaminant Hazard Review: Biological report 32 US Fish and wildlife Service, Laurel, MD, p. 63.

Erwin, P.M., Olson, J.B., Thacker, R.W., 2011. Phylogenetic diversity, host-specificity and community profiling of sponge-associated bacteria in the Northern Gulf of Mexico. PLoS ONE 6, e26806.

Féral, J.P., Fusey, P., Gaill, F., Lopez, E., Martelly, E., Oudot, J., Van Praët, M., 1979. Evolution des teneurs en hydrocarbures chez quelques organismes marins $\mathrm{du}$ Nord Finistère depuis l'échouage de l'Amoco Cadiz et comparaison des méthodes de dosage en infrarouge et spectrofluorimétrie. C. R. Acad. Sci. Paris. 288, 713-716.

Gadd, G.M., 1990. Heavy metal accumulation by bacteria and other microorganisms. Experientia 46, 834-840.

Hansen, I.V., Weeks, J.M., Depledge, M.H., 1995. Accumulation of copper, zinc, cadmium and chromium by the marine sponge Halichondria panicea pallas and the implications for biomonitoring. Mar. Pollut. Bull. 31, 133-138.

Hédouin, L., Metian, M., Teyssie, J.L., Fowler, S.W., Fichez, R., Warnau, M., 2006. Allometric relationships in the bioconcentration of heavy metals by the edible tropical clam Gafrarium tumidum. Sci. Total Environ. 366, 154-163. 
Hervé-Fernandez, P., Houlbrèque, F., Boisson, F., Mulsow, S., Teyssié, J.-L., Oberhänsli, F., Azemard, S., Jeffree, R., 2010. Cadmium bioaccumulation and retention kinetics in the Chilean blue mussel Mytilus chilensis: Seawater and food exposure pathways. Aquat. Toxicol. 99, 448-456.

Hooper, J.N.A., Van Soest, R.W.M., 2002. Systema Porifera: a guide to the classification of Sponges. Kluwer Academic/Plenum Publishers, New York.

Höss, S., Schlottmann, K., Traunspurger, W., 2011. Toxicity of ingested cadmium to the nematode Caenorhabditis elegans. Environ. Sci. Technol. 45, 10219-10225.

Jeffree, R., Oberhänsli, F., Teyssié, J.-L., 2010. Phylogenetic consistencies among chondrichthyan and teleost fishes in their bioaccumulation of multiple trace elements from seawater. Sci. Total Environ. 408, 3200-3210.

Johnston, E.L., Roberts, D.A., 2009. Contaminants reduce the richness and evenness of marine communities: A review and meta-analysis. Environ. Pollut. 157, 1745-1752.

Junqua, S., Robert, L., Garrone, R., De Ceccatty, M.P., Vacelet, J., 1974. Biochemical and morphological studies on collagens of horny sponges. Ircinia filaments compared to spongines. Connect. Tissue Res. 2, 193-203.

Ke, C., Yu, K.N., Lam, P.K.S., Wang, W.-X., 2000. Uptake and depuration of cesium in the green mussel Perna viridis. Mar. Biol. 137, 567-575.

Lacoue-Labarthe, T., Warnau, M., Oberhänsli, F., Teyssié, J.-L., Bustamante, P., 2010. Contrasting accumulation biokinetics and distribution of ${ }^{241} \mathrm{Am}, \mathrm{Co}, \mathrm{Cs}, \mathrm{Mn}$ and $\mathrm{Zn}$ during the whole development time of the eggs of the common cuttlefish, Sepia officinalis. J. Exp. Mar. Biol. Ecol. 382, 131-138.

Lyons, B.P., Thain, J.E., Stentiford, G.D., Hylland, K., Davies, I.M., Vethaak, A.D., 2010. Using biological effects tools to define good environmental status under the European Union Marine Strategy Framework Directive. Mar. Pollut. Bull. 60, 1647-1651.

Mayol, L., Piccialli, V., Sica, D., 1987. Nitrogenous sesquiterpenes from the marine sponge Acanthella acuta: three new isocyanide-isothiocyanate pairs. Tetrahedron 43, 53815388.

Mertz, W., 1981. The essential trace elements. Science 213, 1332.

de Mestre, C., Maher, W., Roberts, D., Broad, A., Krikowa, F., Davis, A.R., 2012. Sponges as sentinels: Patterns of spatial and intra-individual variation in trace metal concentration. Mar. Pollut. Bull. 64, 80-89.

Metian, M., Bustamante, P., Cosson, R.P., Hédouin, L., Warnau, M., 2008. Investigation of $\mathrm{Ag}$ in the king scallop Pecten maximus using field and laboratory approaches. J. Exp. Mar. Biol. Ecol. 367, 53-60.

Metian, M., Hédouin, L., Eltayeb, M.M., Lacoue-Labarthe, T., Teyssié, J.-L., Mugnier, C., Bustamante, P., Warnau, M., 2010. Metal and metalloid bioaccumulation in the Pacific blue shrimp Litopenaeus stylirostris (Stimpson) from New Caledonia: Laboratory and field studies. Mar. Pollut. Bull. 61, 576-584.

Metian, M., Warnau, M., Hédouin, L., Bustamante, P., 2009. Bioaccumulation of essential metals (Co, Mn and $\mathrm{Zn}$ ) in the king scallop Pecten maximus: seawater, food and sediment exposures. Mar. Biol. 156, 2063-2075.

Metian, M., Warnau, M., Teyssié, J.-L., Bustamante, P., 2011. Characterization of ${ }^{241}$ Am and ${ }^{134} \mathrm{Cs}$ bioaccumulation in the king scallop Pecten maximus: investigation via three exposure pathways. J. Environ. Radioact. 102, 543-550.

Müller, W.E.G., Borejko, A., Brandt, D., Osinga, R., Ushijima, H., Hamer, B., Krasko, A., Xupeng, C., Müller, I.M., Schröder, H.C., 2005. Selenium affects biosilica formation in the demosponge Suberites domuncula. FEBS J. 272, 3838-3852. 
Pan, K., Lee, O.O., Qian, P.Y., Wang, W.X., 2011. Sponges and sediments as monitoring tools of metal contamination in the eastern coast of the Red Sea, Saudi Arabia. Mar. Pollut. Bull. 62, 1140-1146.

Patel, B., Balani, M.C., Patel, S., 1985. Sponge "sentinel" of heavy metals. Sci. Total Environ. 41, 143-152.

Patel, B., Patel, S., Taylor, D.M., 1984. The chemical form of cobalt-60 in the marine sponge Spirastrella cuspidifera. Mar. Biol. 80, 45-48.

Pérez, T., 2000. Evaluation de la qualité des milieux côtiers par les spongiaires: état de l'art. Bull. Soc. Zool. Fr. 125, 17-25.

Pérez, T., Longet, D., Schembri, T., Rebouillon, P., Vacelet, J., 2005. Effects of 12 years' operation of a sewage treatment plant on trace metal occurrence within a Mediterranean commercial sponge (Spongia officinalis, Demospongiae). Mar. Pollut. Bull. 50, 301309.

Pérez, T., Vacelet, J., Rebouillon, P., 2004. In situ comparative study of several Mediterranean sponges as potential biomonitors of heavy metals. Boll. Mus. Ist. Biol. Univ. Genova 68, 517-525.

Pérez, T., Wafo, E., Fourt, M., Vacelet, J., 2003. Marine sponges as biomonitor of polychlorobiphenyl contamination: concentration and fate of 24 congeners. Environ. Sci. Technol. 37, 2152-2158.

Phillips, D.J.H., 1990. Use of macroalgae and invertebrates as monitors of metal levels in estuaries and coastal waters, in: Furness, R.W., Rainbow, P.S. (Eds.), Heavy Metals in the Marine Environment CRC Press, Boca Raton, FL, pp. 81-99.

R Development Core Team, 2008. R: a language and environment for statistical computing, Vienna, Austria: R Foundation for Statistical Computing, accessed: http://www.Rproject.org.

Rainbow, P.S., 1995. Biomonitoring of heavy metal availability in the marine environment. Mar. Pollut. Bull. 31, 183-192.

Rainbow, P.S., Phillips, D.J.H., 1993. Cosmopolitan biomonitors of trace metals. Mar. Pollut. Bull. 26, 593-601.

Roberts, D.A., Johnston, E.L., Poore, A.G.B., 2008. Biomonitors and the assessment of ecological impacts: Distribution of herbivorous epifauna in contaminated macroalgal beds. Environ. Poll. 156, 489-503.

Ryan, T.P., 2002. Transuranic biokinetic parameters for marine invertebrates-a review. Environ. Int. 28, 83-96.

Schwertner, H., Müller, W.E.G., Schröder, H.C., Osinga, R., 2006. Selenium-enriched liquid media for the cultivation of siliceous sponges and for biogenic silica production, Biotecmarin. WO 2006/131306, Germany.

Selvin, J., Shanmugha Priya, S., Seghal Kiran, G., Thangavelu, T., Sapna Bai, N., 2009. Sponge-associated marine bacteria as indicators of heavy metal pollution. Microbiol. Res. 164, 352-363.

Stadtman, T.C., 1996. Selenocysteine. Annu. Rev. Biochem. 65, 83-100.

Taylor, M.W., Radax, R., Steger, D., Wagner, M., 2007. Sponge-associated microorganisms: evolution, ecology, and biotechnological potential. Microbiol. Mol. Biol. Rev. 71, 295.

Turon, X., Galera, J., Uriz, M.J., 1997. Clearance rates and aquiferous systems in two sponges with contrasting life-history strategies. J. Exp. Zool. 278, 22-36.

Van der Oost, R., Beyer, J., Vermeulen, N.P.E., 2003. Fish bioaccumulation and biomarkers in environmental risk assessment: a review. Environ. Toxicol. Pharmacol. 13, 57-149.

Venkateswara Rao, J., Srikanth, K., Pallela, R., Gnaneshwar Rao, T., 2009. The use of marine sponge, Haliclona tenuiramosa as bioindicator to monitor heavy metal pollution in the coasts of Gulf of Mannar, India. Environ. Monit. Assess. 156, 451-459. 
Verdenal, B., Diana, C., Arnoux, A., Vacelet, J., 1990. Pollutant levels in Mediterranean commercial sponges, in: Rützler, K. (Ed.), New Perspectives in Sponge Biology. Smithsonian Institution Press, Washington, DC, USA, pp. 516-524.

Wang, W.-X., Fisher, N.S., Luoma, S.N., 1996. Kinetic determination of trace element bioaccumulation in the mussel Mytilus edulis. Mar. Ecol. Prog. Ser. 140, 91-113.

Wang, W.X., Ke, C., Yu, K.N., Lam, P.K.S., 2000. Modeling radiocesium bioaccumulation in a marine food chain. Mar. Ecol. Prog. Ser. 208, 41-50.

Warnau, M., Bustamante, P., 2007. Radiotracer techniques: A unique tool in marine ecotoxicological studies. Environ. Bioindic. 2, 217-218.

Warnau, M., Fowler, S.W., Teyssie, J.-L., 1999. Biokinetics of radiocobalt in the asteroid Asterias rubens (Echinodermata): sea water and food exposures. Mar. Pollut. Bull. 39, 159-164.

Warnau, M., Teyssié, J.-L., Fowler, S.W., 1996. Biokinetics of selected heavy metals and radionuclides in the common Mediterranean echinoid Paracentrotus lividus: seawater and food exposures. Mar. Ecol. Prog. Ser. 141, 83-94.

Weisz, J.B., Lindquist, N., Martens, C., 2008. Do associated microbial abundances impact marine demosponge pumping rates and tissue densities? Oecologia 155, 367-376.

Whicker, F.W., Schultz, V., 1982. Radioecology: nuclear energy and the environment. CRC Press, Boca Raton, FL.

Winkel, L., Johnson, A., Lenz, M., Grundl, T., Leupin, O.X., Amini, M., Charlet, L., 2012. Environmental Selenium Research: from Microscopic Processes to Global Understanding. Environ. Sci. Technol. 46, 571-579.

Zhou, Q., Zhang, J., Fu, J., Shi, J., Jiang, G., 2008. Biomonitoring: An appealing tool for assessment of metal pollution in the aquatic ecosystem. Anal. Chim. Acta 606, 135-150. 


\section{Captions to Figures}

Fig. 1. Metal and radionuclide uptake kinetics $(\mathrm{CF}$; mean $\pm \mathrm{SD} ; \mathrm{n}=3)$ in the whole body of Acanthella acuta $(\triangle)$, Agelas oroides $(\bullet)$, Cymbaxinella damicornis $(\bigcirc)$, Cymbaxinella verrucosa

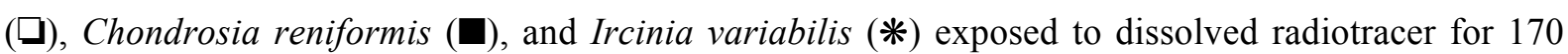
hours. Model parameters are reported in Table 1. Please note the logarithmic scale for ${ }^{110 \mathrm{~m}} \mathrm{Ag} \mathrm{CF}$.

Fig. 2. Metal and radionuclide loss kinetics $(\mathrm{CF} ;$ mean $\pm \mathrm{SD} ; \mathrm{n}=3)$ in the whole body of Acanthella acuta $(\triangle)$, Agelas oroides $(\bullet)$, Cymbaxinella damicornis (○), Cymbaxinella verrucosa $(\square)$, Chondrosia reniformis (घ), and Ircinia variabilis (*) exposed to dissolved radiotracer for 170 hours. Model parameters are reported in Table 1.

Fig. 3. Hierarchical Clustering on Principal Components for $\mathrm{CF}_{170 \mathrm{~h}}$ values. 

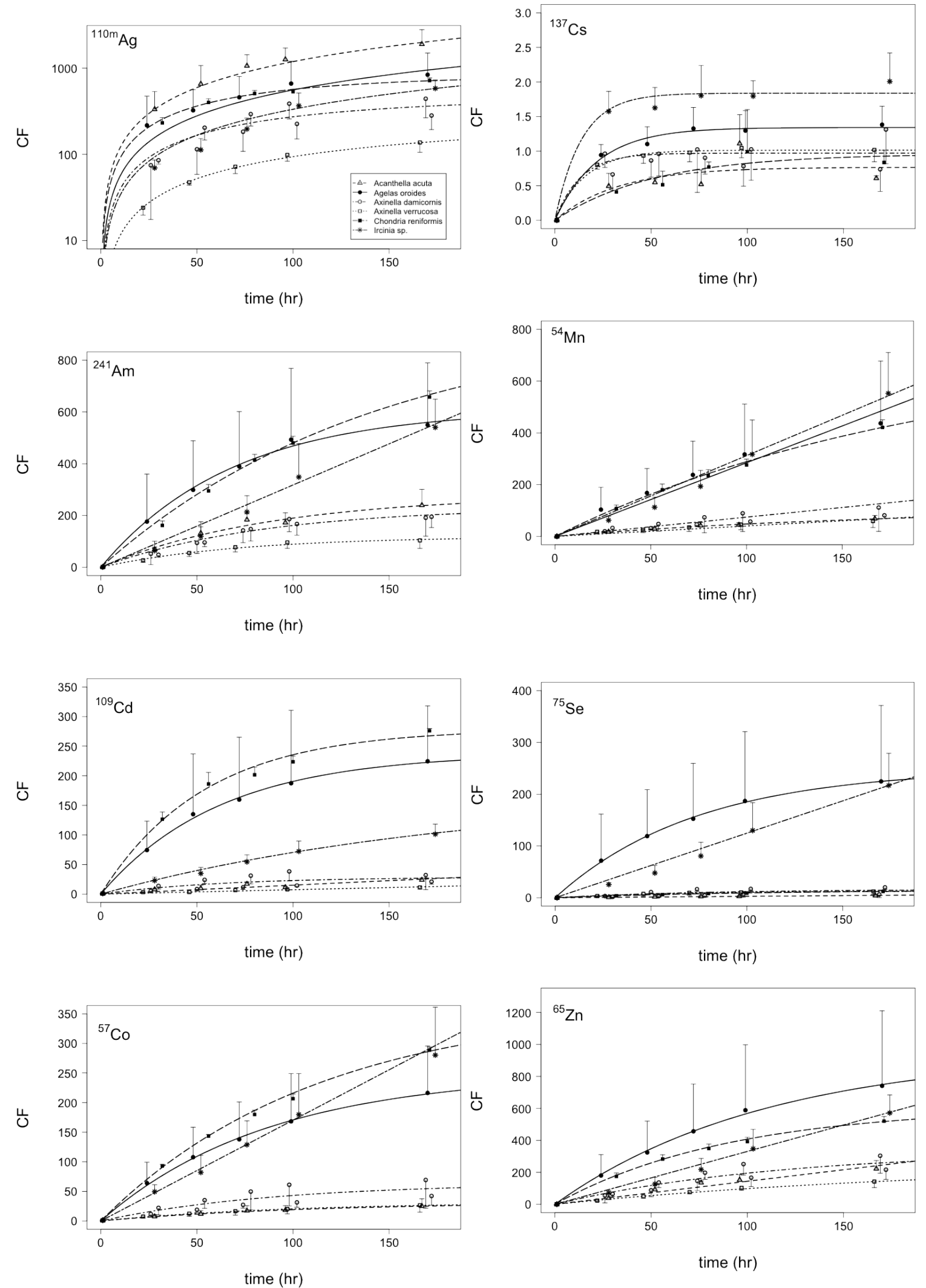

Figure 1 

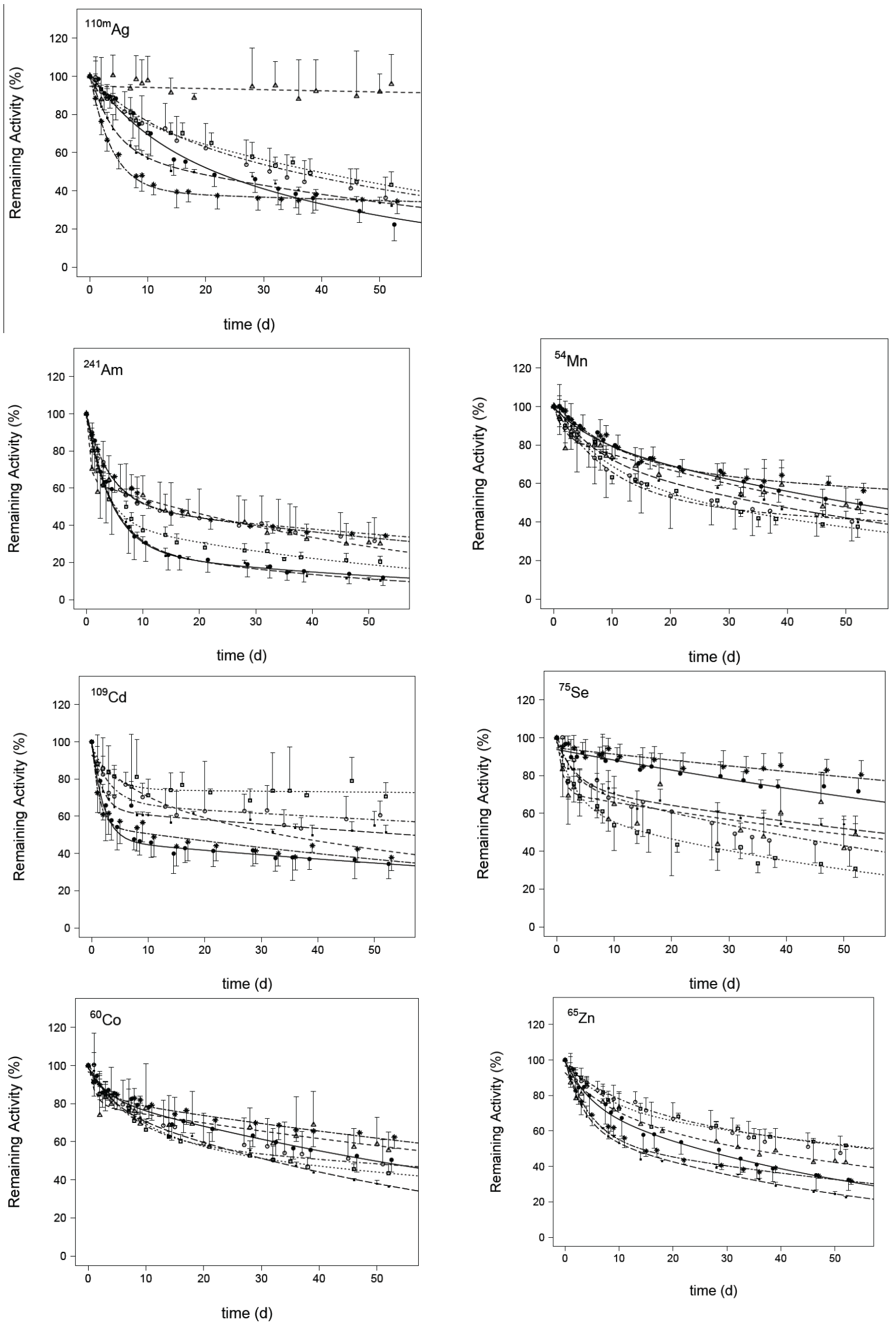

Figure 2 


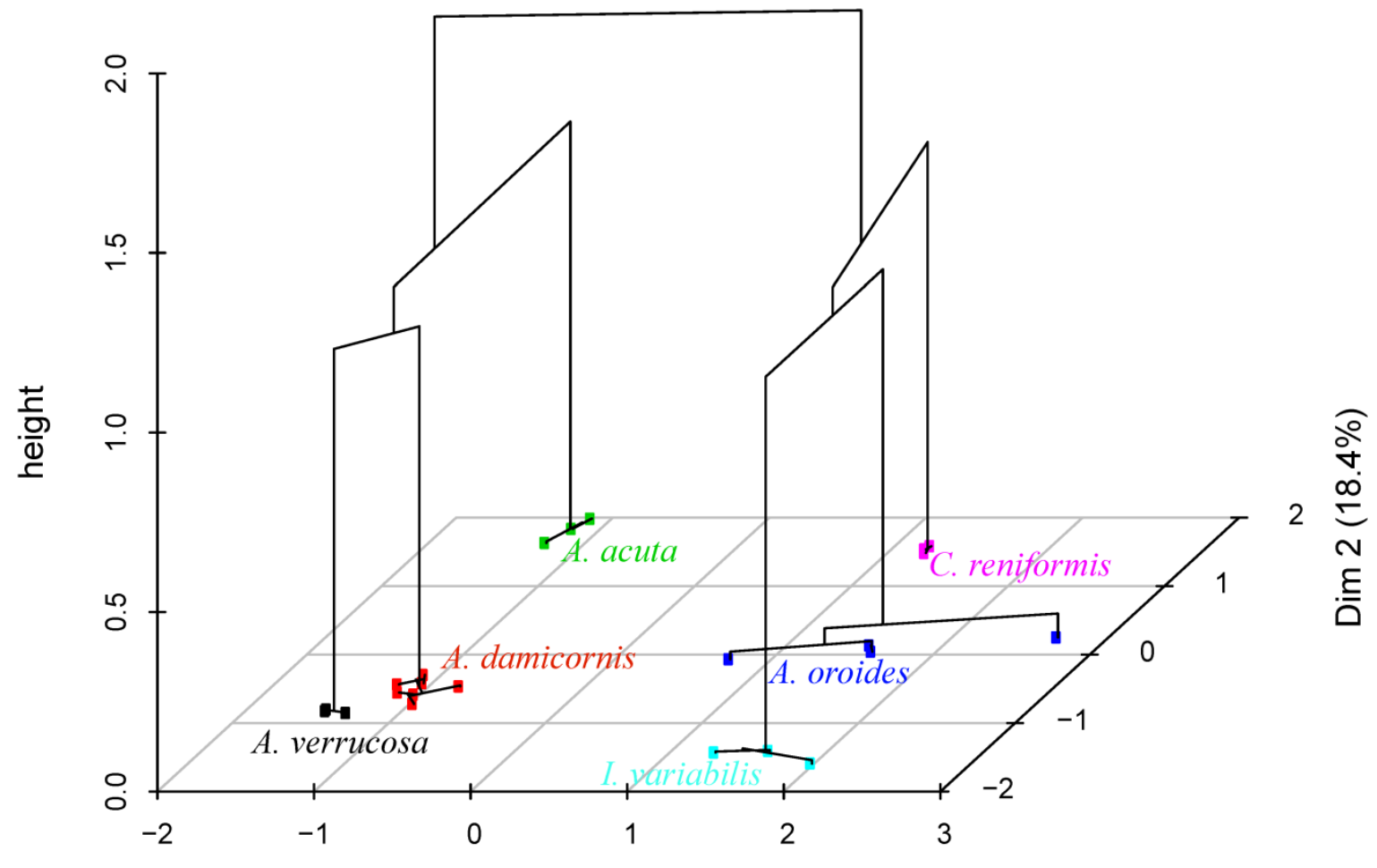

$\operatorname{Dim} 1$ (29.08\%)

Figure 3 
Table 1. Parameters of metal uptake kinetics (CF; mean $\pm \mathrm{SD}, \mathrm{n}=3)$ in the six species of sponge exposed for 170 hours to radiotracers dissolved in seawater (see Figure 1):

\begin{tabular}{|c|c|c|c|c|c|c|}
\hline Metal & Species & Model & $\mathrm{k}_{\mathrm{u}} \pm \mathrm{SE}$ & $\mathrm{CF}_{\mathrm{ss}} \pm \mathrm{SE}$ & $R^{2}$ & $\mathrm{CF}_{170 \mathrm{~h}}$ \\
\hline \multirow{6}{*}{${ }^{110 \mathrm{~m}} \mathrm{Ag}$} & A. acuta & $\mathrm{L}$ & $11.9 \pm 1.1$ & - & 0.878 & $1895 \pm 896$ \\
\hline & A. oroides & $\mathrm{L}$ & $5.6 \pm 0.8$ & - & 0.659 & $838 \pm 657$ \\
\hline & C. damicornis & $\mathrm{E}$ & $4.1 \pm 2.2$ & $466 \pm 127$ & 0.771 & $351 \pm 147$ \\
\hline & C. verrucosa & $\mathrm{E}$ & $1.2 \pm 0.7$ & $261 \pm 92$ & 0.963 & $137 \pm 32$ \\
\hline & C. reniformis & E & $9.6 \pm 1.3$ & $829 \pm 51$ & 0.989 & $717 \pm 52$ \\
\hline & I. variabilis & $\mathrm{L}$ & $3.3 \pm 0.2$ & - & 0.931 & $581 \pm 147$ \\
\hline \multirow[t]{6}{*}{${ }^{241} \mathrm{Am}$} & A. acuta & $\mathrm{E}$ & $3.2 \pm 1.2$ & $280 \pm 50$ & 0.920 & $240 \pm 61$ \\
\hline & A. oroides & $\mathrm{E}$ & $8.9 \pm 5.5$ & $612 \pm 159$ & 0.723 & $550 \pm 239$ \\
\hline & C. damicornis & $\mathrm{E}$ & $2.7 \pm 0.8$ & $237 \pm 32$ & 0.892 & $196 \pm 46$ \\
\hline & C. verrucosa & E & $1.6 \pm 0.6$ & $119 \pm 18$ & 0.919 & $104 \pm 31$ \\
\hline & C. reniformis & $\mathrm{E}$ & $6.7 \pm 0.8$ & $960 \pm 66$ & 0.996 & $658 \pm 24$ \\
\hline & I. variabilis & $\mathrm{L}$ & $3.2 \pm 0.2$ & - & 0.950 & $540 \pm 109$ \\
\hline \multirow[t]{6}{*}{${ }^{109} \mathrm{Cd}$} & A. acuta & $\mathrm{L}$ & $0.2 \pm 0.01$ & - & 0.919 & $24 \pm 3$ \\
\hline & A. oroides & $\mathrm{E}$ & $3.8 \pm 2.4$ & $238 \pm 61$ & 0.692 & $224 \pm 94$ \\
\hline & C. damicornis & $\mathrm{E}$ & $0.5 \pm 0.3$ & $33 \pm 8$ & 0.687 & $28 \pm 15$ \\
\hline & C. verrucosa & $\mathrm{L}$ & $0.07 \pm 0.01$ & - & 0.936 & $12 \pm 3$ \\
\hline & C. reniformis & $\mathrm{E}$ & $5.2 \pm 0.1$ & $279 \pm 11$ & 0.989 & $276 \pm 4$ \\
\hline & I. variabilis & $\mathrm{E}$ & $0.9 \pm 0.5$ & $172 \pm 53$ & 0.957 & $101 \pm 17$ \\
\hline \multirow[t]{6}{*}{${ }^{60} \mathrm{Co}$} & A. acuta & E & $0.3 \pm 0.2$ & $32 \pm 13$ & 0.801 & $25 \pm 12$ \\
\hline & A. oroides & E & $2.9 \pm 1.6$ & $250 \pm 63$ & 0.809 & $216 \pm 79$ \\
\hline & C. damicornis & $\mathrm{E}$ & $0.7 \pm 0.4$ & $64 \pm 19$ & 0.633 & $54 \pm 33$ \\
\hline & C. verrucosa & $\mathrm{E}$ & $0.3 \pm 0.2$ & $32 \pm 10$ & 0.839 & $27 \pm 12$ \\
\hline & C. reniformis & $\mathrm{E}$ & $3.2 \pm 0.2$ & $366 \pm 14$ & 0.998 & $289 \pm 5$ \\
\hline & I. variabilis & $\mathrm{L}$ & $1.7 \pm 0.1$ & - & 0.934 & $280 \pm 81$ \\
\hline \multirow[t]{6}{*}{${ }^{134} \mathrm{Cs}$} & A. acuta* & $\mathrm{E}$ & $0.03 \pm 0.01$ & $0.7 \pm 0.1$ & 0.725 & $0.6 \pm 0.04$ \\
\hline & A. oroides & $\mathrm{E}$ & $0.06 \pm 0.02$ & $1.3 \pm 0.1$ & 0.914 & $1.4 \pm 0.3$ \\
\hline & C. damicornis & E & $0.07 \pm 0.04$ & $1.0 \pm 0.1$ & 0.593 & $1.1 \pm 0.5$ \\
\hline & C. verrucosa & $\mathrm{E}$ & $0.06 \pm 0.01$ & $1.0 \pm 0.03$ & 0.965 & $1.0 \pm 0.2$ \\
\hline & C. reniformis & $\mathrm{E}$ & $0.02 \pm 0.01$ & $1.0 \pm 0.2$ & 0.793 & $0.8 \pm 0.2$ \\
\hline & I. variabilis & E & $0.13 \pm 0.05$ & $1.8 \pm 0.1$ & 0.925 & $2.0 \pm 0.4$ \\
\hline
\end{tabular}


Table 1 (following). Parameters of metal uptake kinetics (CF; mean $\pm \mathrm{SD}, \mathrm{n}=3$ ) in the six species of sponge exposed for 170 hours to radiotracers dissolved in seawater (see Figure 1):

\begin{tabular}{|c|c|c|c|c|c|c|}
\hline Metal & Species & Model & $\mathrm{k}_{\mathrm{u}} \pm \mathrm{SE}$ & $\mathrm{CF}_{\mathrm{ss}} \pm \mathrm{SE}$ & $R^{2}$ & $\mathrm{CF}_{170 \mathrm{~h}}$ \\
\hline \multirow[t]{6}{*}{${ }^{54} \mathrm{Mn}$} & A. acuta & E & $0.6 \pm 0.3$ & $107 \pm 31$ & 0.949 & $68 \pm 13$ \\
\hline & A. oroides & $\mathrm{L}$ & $2.8 \pm 0.3$ & - & 0.787 & $437 \pm 240$ \\
\hline & C. damicornis & $\mathrm{L}$ & $0.6 \pm 0.1$ & - & 0.744 & $94 \pm 56$ \\
\hline & C. verrucosa & $\mathrm{L}$ & $0.4 \pm 0.03$ & - & 0.860 & $59 \pm 25$ \\
\hline & C. reniformis & E & $3.7 \pm 0.9$ & $727 \pm 101$ & 0.991 & $421 \pm 29$ \\
\hline & I. variabilis & $\mathrm{L}$ & $3.1 \pm 0.2$ & - & 0.929 & $553 \pm 157$ \\
\hline \multirow[t]{6}{*}{${ }^{75} \mathrm{Se}$} & A. acuta & $\mathrm{L}$ & $0.02 \pm 0.001$ & - & 0.926 & $4 \pm 1$ \\
\hline & A. oroides & $\mathrm{E}$ & $3.4 \pm 2.8$ & $250 \pm 90$ & 0.629 & $225 \pm 147$ \\
\hline & C. damicornis & $\mathrm{E}$ & $0.2 \pm 0.1$ & $16 \pm 5$ & 0.605 & $14 \pm 8$ \\
\hline & C. verrucosa & $\mathrm{E}$ & $0.2 \pm 0.1$ & $13 \pm 3$ & 0.767 & $12 \pm 6$ \\
\hline & C. reniformis & $\mathrm{E}$ & $0.1 \pm 0.01$ & $16 \pm 1$ & 0.996 & $12 \pm 1$ \\
\hline & I. variabilis & $\mathrm{L}$ & $1.2 \pm 0.1$ & - & 0.931 & $217 \pm 62$ \\
\hline \multirow[t]{6}{*}{${ }^{65} \mathrm{Zn}$} & A. acuta & $\mathrm{L}$ & $1.4 \pm 0.1$ & - & 0.955 & $223 \pm 51$ \\
\hline & A. oroides & $\mathrm{E}$ & $8.7 \pm 8.2$ & $951 \pm 456$ & 0.692 & $741 \pm 469$ \\
\hline & C. damicornis & $\mathrm{E}$ & $2.9 \pm 1.3$ & $337 \pm 79$ & 0.817 & $254 \pm 89$ \\
\hline & C. verrucosa & E & $1.2 \pm 0.8$ & $263 \pm 100$ & 0.954 & $142 \pm 37$ \\
\hline & C. reniformis & E & $6.7 \pm 0.8$ & $610 \pm 33$ & 0.992 & $520 \pm 29$ \\
\hline & I. variabilis & $\mathrm{L}$ & $3.3 \pm 0.2$ & - & 0.954 & $571 \pm 113$ \\
\hline
\end{tabular}

L and E: linear and exponential models, respectively; $\mathrm{CF}_{\mathrm{ss}}$ : concentration factor at steady-state, $\mathrm{k}_{\mathrm{u}}\left(\mathrm{h}^{-}\right.$ $\left.{ }^{1}\right)$ : uptake rate, respectively; SE: standard error; $\mathrm{R}^{2}$ : determination coefficient.

${ }^{*}{ }^{134} \mathrm{Cs}$ uptake was probably underestimated in $A$. acuta because of the high accumulation of ${ }^{110 \mathrm{~m}} \mathrm{Ag}$. 
Table 2. Parameters and statistics of the depuration kinetics of radiotracers in the six species of sponge previously seawater exposed for 170 hours:

\begin{tabular}{|c|c|c|c|c|c|c|}
\hline Metal & Species & Model & $\mathrm{A}_{01} \pm \mathrm{SE}(\%)$ & $\mathrm{k}_{\mathrm{el}}$ & $\mathrm{T}_{\mathrm{b}^{1 / 2}} \pm \mathrm{SE}(\mathrm{d})$ & $\mathrm{R}^{2}$ \\
\hline \multirow[t]{6}{*}{${ }^{110 \mathrm{~m}} \mathrm{Ag}$} & A. acuta & $\mathrm{O}$ & $95 \pm 3$ & $0.0006^{\mathrm{ns}}$ & $1093 \pm 1773$ & 0.085 \\
\hline & A. oroides & $\mathrm{T}$ & $72 \pm 32$ & $0.020^{*}$ & $35 \pm 17$ & 0.955 \\
\hline & C. damicornis & $\mathrm{T}$ & $76 \pm 24$ & $0.013^{\mathrm{ns}}$ & $55 \pm 29$ & 0.912 \\
\hline & C. verrucosa & $\mathrm{T}$ & $83 \pm 4$ & $0.013 * * *$ & $54 \pm 7$ & 0.973 \\
\hline & C. reniformis & $\mathrm{T}$ & $61 \pm 2$ & $0.012 * * *$ & $60 \pm 6$ & 0.990 \\
\hline & I. variabilis & $\mathrm{T}$ & $39 \pm 3$ & $0.002^{\mathrm{ns}}$ & $285 \pm 301$ & 0.965 \\
\hline \multirow[t]{6}{*}{${ }^{241} \mathrm{Am}$} & A. acuta & $\mathrm{T}$ & $64 \pm 3$ & $0.016 * * *$ & $43 \pm 5$ & 0.901 \\
\hline & A. oroides & $\mathrm{T}$ & $27 \pm 11$ & $0.015^{\mathrm{ns}}$ & $47 \pm 38$ & 0.920 \\
\hline & C. damicornis & $\mathrm{T}$ & $50 \pm 6$ & $0.007 *$ & $99 \pm 48$ & 0.854 \\
\hline & C. verrucosa & $\mathrm{T}$ & $42 \pm 3$ & $0.016^{* * *}$ & $43 \pm 3$ & 0.980 \\
\hline & C. reniformis & $\mathrm{T}$ & $30 \pm 3$ & $0.020 * * *$ & $35 \pm 6$ & 0.994 \\
\hline & I. variabilis & $\mathrm{T}$ & $52 \pm 3$ & $0.009 * * *$ & $77 \pm 14$ & 0.985 \\
\hline \multirow[t]{6}{*}{${ }^{109} \mathrm{Cd}$} & A. acuta & - & - & - & - & - \\
\hline & A. oroides & $\mathrm{T}$ & $47 \pm 3$ & $0.006^{* *}$ & $116 \pm 49$ & 0.920 \\
\hline & C. damicornis & $\mathrm{T}$ & $67 \pm 5$ & $0.003^{\mathrm{ns}}$ & $249 \pm 195$ & 0.641 \\
\hline & C. verrucosa & $\mathrm{T}$ & $74 \pm 6$ & $0.0004^{\mathrm{ns}}$ & $1950 \pm 12890$ & 0.544 \\
\hline & C. reniformis & $\mathrm{T}$ & $63 \pm 1$ & $0.004 * * *$ & $167 \pm 29$ & 0.955 \\
\hline & I. variabilis & $\mathrm{T}$ & $55 \pm 3$ & $0.008 * * *$ & $88 \pm 23$ & 0.887 \\
\hline \multirow[t]{6}{*}{${ }^{60} \mathrm{Co}$} & A. acuta & $\mathrm{T}$ & $79 \pm 4$ & $0.006 * *$ & $110 \pm 32$ & 0.672 \\
\hline & A. oroides & $\mathrm{T}$ & $84 \pm 3$ & $0.011 * * *$ & $66 \pm 8$ & 0.933 \\
\hline & C. damicornis & $\mathrm{T}$ & $60 \pm 13$ & $0.004^{\mathrm{ns}}$ & $157 \pm 188$ & 0.641 \\
\hline & C. verrucosa & $\mathrm{T}$ & $60 \pm 14$ & $0.006^{\mathrm{ns}}$ & $113 \pm 99$ & 0.949 \\
\hline & C. reniformis & $\mathrm{T}$ & $80 \pm 2$ & $0.015 * * *$ & $46 \pm 2$ & 0.993 \\
\hline & I. variabilis & $\mathrm{T}$ & $83 \pm 3$ & $0.006 * * *$ & $118 \pm 25$ & 0.866 \\
\hline \multirow[t]{6}{*}{${ }^{134} \mathrm{Cs}$} & A. acuta & - & - & - & - & - \\
\hline & A. oroides & - & - & - & - & - \\
\hline & C. damicornis & - & - & - & - & - \\
\hline & C. verrucosa & - & - & - & - & - \\
\hline & C. reniformis & - & - & - & - & - \\
\hline & I. variabilis & - & - & - & - & - \\
\hline
\end{tabular}


Table 2 (following). Parameters and statistics of the depuration kinetics of radiotracers in the six species of sponge previously seawater exposed for 170 hours:

\begin{tabular}{|c|c|c|c|c|c|c|}
\hline Metal & Species & Model & $\mathrm{A}_{01} \pm \mathrm{SE}(\%)$ & $\mathrm{k}_{\mathrm{el}}$ & $\mathrm{T}_{\mathrm{b}^{\prime} / 2} \pm \mathrm{SE}(\mathrm{d})$ & $\mathrm{R}^{2}$ \\
\hline \multirow[t]{6}{*}{${ }^{54} \mathrm{Mn}$} & A. acuta & $\mathrm{T}$ & $84 \pm 3$ & $0.011 * * *$ & $61 \pm 8$ & 0.865 \\
\hline & A. oroides & $\mathrm{T}$ & $85 \pm 8$ & $0.010 * * *$ & $67 \pm 16$ & 0.929 \\
\hline & C. damicornis & $\mathrm{T}$ & $50 \pm 17$ & $0.004^{\mathrm{ns}}$ & $179 \pm 338$ & 0.862 \\
\hline & C. verrucosa & $\mathrm{T}$ & $61 \pm 14$ & $0.010^{\mathrm{ns}}$ & $69 \pm 34$ & 0.976 \\
\hline & C. reniformis & $\mathrm{T}$ & $75 \pm 5$ & $0.012 * * *$ & $60 \pm 9$ & 0.986 \\
\hline & I. variabilis & $\mathrm{T}$ & $67 \pm 14$ & $0.003^{\mathrm{ns}}$ & $240 \pm 349$ & 0.945 \\
\hline \multirow[t]{6}{*}{${ }^{75} \mathrm{Se}$} & A. acuta & $\mathrm{T}$ & $71 \pm 5$ & $0.008 * *$ & $93 \pm 33$ & 0.627 \\
\hline & A. oroides & $\mathrm{O}$ & $94 \pm 1$ & $0.006^{* * *}$ & $112 \pm 12$ & 0.772 \\
\hline & C. damicornis & $\mathrm{T}$ & $76 \pm 6$ & $0.011 * * *$ & $61 \pm 14$ & 0.753 \\
\hline & C. verrucosa & $\mathrm{T}$ & $62 \pm 6$ & $0.014 * * *$ & $49 \pm 11$ & 0.937 \\
\hline & C. reniformis & $\mathrm{T}$ & $74 \pm 3$ & $0.007 * * *$ & $99 \pm 15$ & 0.955 \\
\hline & I. variabilis & $\mathrm{O}$ & $95 \pm 1$ & $0.004 * * *$ & $197 \pm 37$ & 0.612 \\
\hline \multirow[t]{6}{*}{${ }^{65} \mathrm{Zn}$} & A. acuta & $\mathrm{T}$ & $68 \pm 24$ & $0.010^{\mathrm{ns}}$ & $73 \pm 57$ & 0.898 \\
\hline & A. oroides & $\mathrm{T}$ & $75 \pm 7$ & $0.017 * * *$ & $42 \pm 8$ & 0.937 \\
\hline & C. damicornis & $\mathrm{T}$ & $71 \pm 18$ & $0.006^{\mathrm{ns}}$ & $112 \pm 88$ & 0.894 \\
\hline & C. verrucosa & $\mathrm{T}$ & $73 \pm 6$ & $0.007 * *$ & $104 \pm 34$ & 0.961 \\
\hline & C. reniformis & $\mathrm{T}$ & $61 \pm 2$ & $0.018 * * *$ & $38 \pm 2$ & 0.994 \\
\hline & I. variabilis & $\mathrm{T}$ & $55 \pm 4$ & $0.011 * * *$ & $66 \pm 13$ & 0.866 \\
\hline
\end{tabular}

$\mathrm{O}$ and T: 1- and 2-component exponential models, respectively; $\mathrm{A}_{01}$ : assimilation efficiency of the long-lived component, respectively; SE: standard error; $\mathrm{R}^{2}$ : determination coefficient; $\mathrm{p}$-values: < $0.001(* * *),<0.01(* *),<0.05(*),>0.5(\mathrm{~ns})$. In the case of T model, only the long-lived component parameters are shown $\left(\mathrm{A}_{01}, \mathrm{k}_{\mathrm{el}}\right.$ and $\left.\mathrm{T}_{\mathrm{b}^{1 / 2}}\right)$ 